\title{
Career Adapt-Ability and Social Support among Trainee
} Teachers

\section{Mohd Izwan Mahmud, Salleh Amat \& Siti Hashimah Ghazali}

To Link this Article: http://dx.doi.org/10.6007/IJARBSS/v12-i1/12293

DOI:10.6007/IJARBSS/v12-i1/12293

Received: 21 November 2021, Revised: 16 December 2021, Accepted: 15 January 2022

Published Online: 30 January 2022

In-Text Citation: (Mahmud et al., 2022)

To Cite this Article: Mahmud, M. I., Amat, S., \& Ghazali, S. H. (2022). Career Adapt-Ability and Social Support among Trainee Teachers. International Journal of Academic Research in Business and Social Sciences, 12(1), 2315-2325.

\section{Copyright: (C) 2022 The Author(s)}

Published by Human Resource Management Academic Research Society (www.hrmars.com)

This article is published under the Creative Commons Attribution (CC BY 4.0) license. Anyone may reproduce, distribute, translate and create derivative works of this article (for both commercial and non0-commercial purposes), subject to full attribution to the original publication and authors. The full terms of this license may be seen at: http://creativecommons.org/licences/by/4.0/legalcode

Vol. 12, No. 1, 2022, Pg. 2315- 2325

Full Terms \& Conditions of access and use can be found at http://hrmars.com/index.php/pages/detail/publication-ethics 


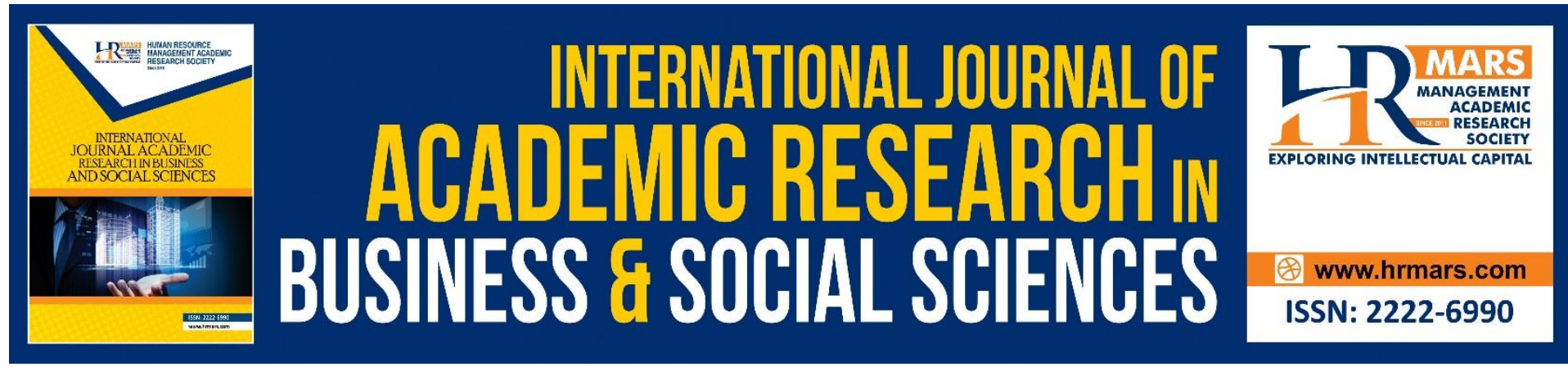

\title{
Career Adapt-Ability and Social Support among Trainee Teachers
}

\author{
Mohd Izwan Mahmud, Salleh Amat \& Siti Hashimah Ghazali \\ Faculty of Education, Universiti Kebangsaan Malaysia, Bangi, Selangor \\ Corresponding Author Email: sallehba@ukm.edu.my
}

\begin{abstract}
Career adapt-ability is a process that each individual need to go through including their attitudes, competencies, and behaviors to adapt to the work environment. While social support is the support from significant family, friends and individuals who contribute to one's personal well-being in the process of career adapt-ability. This study aims to identify the level and relationship between career adapt-ability and social support of undergraduate students. This study uses descriptive and correlation design to measure the level and relationship between the variables. A total of 83 undergraduate students at a public university who were preparing for their internship were involved as respondents of this study. Two instruments were used in this study namely, the Career Adapt-Abilities Scale (CAAS) to measure career adjustment, and the Multidimensional Scale of Perceived Social Support (MSPSS) to measure social support. Findings found that the overall career adapt-ability and social support among undergraduate students are at high level. Findings also showed significant relationship between adapt-ability and friends support $(r=.216, p<.05)$. However, there is no significant relationship between career adapt-ability with family support $(r=.127, p>.05$.$) and$ significant others support $(r=.048, p>.05)$. This study has implications towards counsellor role in developing student's career program in terms of adaptation and social support. Thus, the recommendations for this study are (i) counsellors need to know and be skilled in using instruments; and (ii) further studies should focus on experimental design to measure the impact of an implemented career program.
\end{abstract}

Keywords: Career Adapt-ability, Social Support, Trainee Teachers, Public University

\section{Introduction}

Career adapt-ability is a process that each individual need to go through including their attitudes, competencies, and behaviors to adapt to the work environment (Hirschi et al., 2015). While, social support refers to various material and emotional support that are received from other individuals (Brannon \& Feist, 2004). Brannon and Feist (2004) also suggest that individuals that receive social support from others show positive mental health characteristics, less stressful and have better coping strategies than marginalized individuals. A study by Nasir et al (2016) explains that social support has been identified as a factor influencing better psychological well-being to avoid loneliness and depression. 
Professional and quality teachers are seen to have mastery in terms of knowledge, skills, and professionalism value. Therefore, the Implementation of Blueprint of Teacher Professional Development by the Ministry of Education, Malaysia aims to guide and help teachers in planning career development and continuous professional development (Ministry of Education Malaysia, 2013). This policy also explains the competency development concept where teachers need to be competent in their field of work (Ministry of Education Malaysia, 2019). This policy introduced by the government is a guide for trainee teachers to adapt in the teaching profession and in the process of adaptation to be a professional teacher.

A study conducted in schools in North America found that on average 40 to 50 percent of teachers leave the teaching profession within 5 years of service (Fantilli \& McDougall, 2009). While, the study by Othman and Omar (2014) found that teachers tend to leave the teaching profession due to high work stress which in turn leads to dissatisfaction in the field of employment. In fact, Azita (2012) stated that various workloads apart from the actual task of teaching cause teachers to be depressed. This indicates that depressed teachers tend to leave the teaching profession. In addition to the low level of job adaptation, the social support received also influences the factors of teachers leaving the teaching profession.

Moreover, trainee teachers are often faced with the issue of allowances that are not given to them during their practicum training. Trainee teachers suggest that allowances be given to them because a lot of money is used for the purpose of teaching preparation. Various expenses such as daily necessities, house rent, notes and distribution to students will make the trainee teacher burdened with financial problems. This will have disruptions and impact on the adaptation of trainee teachers as they will face financial problems. Not only that, trainee teachers tend to experience stress due to lack of financial support from parents because they feel ashamed to ask for money from parents. A study by Saeed et al (2013) showed personal factors have relationship with job performance and stress where the worker does not have family support or having family issues tend to have lower job performance which cause stress.

Not only that, career selection as a teacher is not the main choice of trainee teachers. Students fill out the application (Student Admission Division) form online and fill in eight options and students are offered the last option which is not one of the favorite fields and the main choice. A study by Mohamad Bukhori, et al (2015) found that the selection of students to university is based on factors of self-will, friends influence, parental encouragement, choice limitations, career choices, job opportunities, skills, and interests. When offered a non-optional field, students simply study it to complete their studies. There are even students who make course choices at the urging of the family. Students may show good performance throughout their study but once they enter the job market, student will felt tough as they are working in a field not their interest and this may cause the student to be unmotivated which later impact the adjustment of the trainee teacher.

Therefore, this study is seen to have implications for the role of counselors in developing student career programs in terms of adaptation and social support (Mahmud, et al., 2020). In fact, it can also provide exposure to trainee teachers on the importance of social support from those around them on career development (Mahmud, et al., 2021). 


\section{Career Adapt-Ability}

The career adapt-ability seen in this study are based on the constructivist career theory suggested by Mark L. Savickas. This theory looks at the preparation of individuals to choose a career and apply employment in daily life (Ashari et al., 2019). According to this career theory, individuals focus on interests or traits in job selection (Savickas, 2005). In fact, this theory also looks at the work environment can have an impact and influence on individuals in career adaptations (Hirschi, et al., 2015). The concept of constructivist career theory is divided into four parts namely vocational personality, task development, career adaptation dimensions and life themes (Sharf, 2013; Savickas \& Profeli, 2012). As for the dimensions of career adaptation according to Savickas (2005) is divided into 4 dimensions which are selfawareness, self-control, curiosity, and self-confidence. Next, the concept of the life themes is when an individual tells the meaning of a career done through the theme of his life

Buyukoze-kavas (2016) found that positive psychological traits serve as predictors of undergraduate career adapt-ability. A study involving 415 undergraduate university students in Turkey found that students with high resilience, hope and optimistic self-perception were able to adapt and adapt to their careers better. Career adapt-ability helps improve students' ability to prepare in the job market (Di Maggio, et al., 2020). Another study by (Hui et al., 2018) showed that self-esteem was strongly associated with career adaptability, and this relationship was partially mediated by perceived social support.

Next, Monteiro and Almeida (2015) in a study look at the relationship of career adapt-ability and work experience, curriculum activities, and work transitions among Portuguese graduates found that students who working while studying have higher level of self-control as compared to students studying full time. While students who have work, experience have a high level of curiosity that they tend to explore identity, social role, and interest in the career environment they want to venture into. This study found that there is no difference between students who have experience in curriculum activities and students who do not have curriculum experience in university. In addition, students who have difficulties in work transition have lower selfcontrol.

Study by Sahin and Kirdok (2018) who investigate the relationship between career adaptability, subjective well-being and social support found that social support from family, teachers and friends predicted student career adapt-ability. Social support from family is a high predictor of student career adapt-ability because support from family provides career knowledge, verbal, emotional, financial support and as a role model to students. In addition, this study found that friends are the lowest predictors of student career adapt-ability while teachers obtain a moderate level in predicting student career adapt-ability. This study also found the predictor of career adapt-ability to the subjective well-being for students.

\section{Social Support}

Social support in this study is seen to be based on the theory of relationship regulation introduced by Lakey and Orehek (2011). This theory explains that social support provided consistently can be associated with good mental health. According to this theory, the main effect of good mental health is when individuals can regulate feelings, thoughts and behaviors through effective conversation and activities done together. This theory emphasizes how the social support received through social relationships with people around can reduce stress and 
keep a person's mental health at a good level. This theory can explain how the social support received from family, friends, and significant individual help trainee teacher to self-adapt in career adapt-ability (Lakey \& Orehek, 2011).

Various studies related to social support have been widely conducted by past researchers. For example, Stoltz et al (2013) conducted a study on 230 undergraduate students in the field of education. This study measures aspects of career adapt-ability, factor of stress and family lifestyle. The results of the study showed that there was no career adapt-ability subscale related to the stress response scale involving family and friend's support. This study shows that social support from family and friends does not contribute to good stress response in career adapt-ability.

Next, Oztemel and Akyol (2019) found that happiness, social support, and future orientation influence student career adapt-ability. While individuals who receive social support from parents, friends and significant individuals have better career adapt-ability. Study by Murviana Koto et al (2019) found that there is a significant relationship between career adaptability and social support as well as improving student career readiness.

In addition, Wang et al (2017) found that friends support showed a high score compared to support from colleagues and parents. This study also shows that the support of friends and colleagues has a positive effect on self-efficacy and indirect effect on the resilience of nurses who have just started working. This finding also shows the importance of management to understand how to support colleagues, high self-efficacy and create a work environment that can enhance employee self-efficacy.

The objectives of this study are to:

1. Identify the level of career adapt-ability and social support of university students.

2. Measure the relationship between career adapt-ability and social support of university teacher-student.

3. Measure differences between genders for career adapt-ability and social support of university students.

\section{Methodology}

This study uses descriptive and correlation design to measure the level and relationship between the variables. A total of 83 trainee teachers at a public university who were preparing for their internship were involved as respondents. The population of this study consists of educational program students in the field of Sports and Recreation, Teaching English as Second Language (TESL) and Special Education.

The instrument used in this study is Career Adapt Ability Scale (CAAS) by Savickas and Porfeli (2012) to measure career adapt-ability. The measured constructs are self-awareness, selfcontrol, curiosity, and self-confidence. The number of items found in this instrument is 24 items and uses a 5-point Likert scale. Studies by Savickas and Porfeli (2012) show that the Alpha Cronbach value of the overall reliability of this test tool is .92 while the Alpha Cronbach value of reliability for the self-esteem subscale .79 , self-control .74, curiosity .71 and selfconfidence .85 (Hui et al., 2017). 
Multidimensional Scale of Perceived Social Support (MSPSS) tool was developed by Zimet, et al. (1988) used to measure social support in this study. This tool contains 12 items and there are 3 constructs that measure support from family, friends, and significant individuals. The scale used in this questionnaire is a 7-point Likert scale. This questionnaire showed that the Alpha Cronbach value of the overall reliability of the instrument is .91 while the family subscale recorded Alpha Cronbach value of .88, friends .90 and significant individual .96 (Hui, Yuen \& Chen, 2017).

\section{Results}

In this research, descriptive analysis was conducted to study the level of career adapt-ability and social support. Additionally, Pearson Correlation was used to measure the relationship between career adapt-ability and social support.

\section{Level of Career Adapt-ability and Social Support}

Table 1 shows the results of the descriptive analysis of the career adaptability score mean (Mean $=4.07, S D=.602$ ), and four sub scales were Concern (Mean $=4.03$, SD $=699$ ), SelfControl (Mean $=4.09 \mathrm{SD}=.659$ ), Curiosity (Mean $=4.05$, SD .685) and Self-Confidence (Mean $=4.11, \mathrm{SD}=.602$ ). Result shows the level of career adapt-ability (moderate $22.9 \%$, high 77.1\%), sub scales which are Concern (high 79.5\%, moderate $20.5 \%$ ), Self-Control (high $77.1 \%$, moderate $22.9 \%$ ), Curiosity and Self-Confidence (high $79.5 \%$, moderate $20.5 \%$ ). This finding shows that most of students have high and moderate career adapt-ability.

Table 1: Distribution score of career adapt-ability

\begin{tabular}{|c|c|c|c|c|c|c|}
\hline \multicolumn{2}{|c|}{ Category } & CAAS & Concern & Self-Control & Curiosity & Self-Confidence \\
\hline \multicolumn{2}{|c|}{ Mean } & 4.07 & 4.03 & 4.09 & 4.05 & 4.11 \\
\hline \multicolumn{2}{|l|}{ SD } & .602 & .699 & .659 & .685 & .662 \\
\hline \multicolumn{2}{|c|}{ Alpha Cronbach } & .962 & .898 & .872 & .919 & .921 \\
\hline \multirow[t]{3}{*}{ Level } & Low & - & - & - & - & - \\
\hline & Moderate & $22.9 \%$ & $20.5 \%$ & $22.9 \%$ & $20.5 \%$ & $20.5 \%$ \\
\hline & High & $77.1 \%$ & $79.5 \%$ & $77.1 \%$ & $79.5 \%$ & $79.5 \%$ \\
\hline
\end{tabular}

$n=83$

Table 2 shows the result of the social support variable with Mean $=5.39$, SD 1.182. Three dimensions are under the social support which are family dimension (Mean $=5.92$, SD 1.150), friends (Mean $=5.33$, SD 1.402) and significant others (Mean $=4.91$, SD 1.702). The results of the study showed that a total of $58(69.9 \%)$ respondents have high level of social support while $21(25.3 \%)$ respondents have moderate level and a total of 4 respondents (4.8\%) have low level of social support. In addition, the support subscale from the family was at a high level with all $83(100.0 \%)$ respondents agreed to receive high support from the family. While the support from friends and significant others are also in the high level with 81 (97.6\%) respondents have support from friends and 80 (96.4\%) respondents have support from significant others. 
Table 2: Distribution score of social support

\begin{tabular}{|c|c|c|c|c|c|}
\hline \multicolumn{2}{|c|}{ Categorized } & Social Support & Family & Friends & Significant others \\
\hline \multicolumn{2}{|l|}{ Mean } & 4.07 & 5.92 & 5.33 & 4.91 \\
\hline \multicolumn{2}{|l|}{ SD } & .602 & 1.150 & 1.402 & 1.702 \\
\hline \multicolumn{2}{|c|}{ Alpha Cronbach } & .930 & .862 & .944 & .961 \\
\hline \multirow[t]{3}{*}{ Level } & Low & $4.8 \%$ & - & - & - \\
\hline & Moderate & $25.3 \%$ & - & $2.4 \%$ & $3.6 \% \%$ \\
\hline & High & $69.9 \%$ & $100 \%$ & $97.6 \%$ & $96.4 \%$ \\
\hline
\end{tabular}

$n=83$

\section{Correlation between Career Adapt-Ability and Social Support}

Pearson correlation analysis was used to test the strength of the linear relationship between each study variable. Table 3 shows that there is a significant relationship between career adapt-ability and friends support $(r=.216, p<.05)$. However, there was no significant relationship between career adapt-ability with family support $(r=.127, p>.05)$ and significant others support $(r=.048, p>.05)$.

Table 3. Correlation matrix between career adaptability and social support

\begin{tabular}{lcrrr}
\hline & Social Support & \multicolumn{1}{c}{ Family } & \multicolumn{1}{c}{ Friends } & \multicolumn{1}{c}{ Significant others } \\
\hline Career Adapt-Ability & .150 & .127 & $.216^{*}$ & .048 \\
Concern & .181 & $.229^{*}$ & $.227^{*}$ & .035 \\
Self-Control & .065 & .068 & .101 & .006 \\
Curiosity & .151 & .064 & $.224^{*}$ & .086 \\
Self-Confidence & .134 & .087 & .214 & .043 \\
\hline
\end{tabular}

*. Correlation is significant at the 0.05 level (2-tailed).

**. Correlation is significant at the 0.01 level (2-tailed).

\section{Difference between Gender with Career Adapt-Ability and Social Support}

Table 4 shows the result of t-test which found no significant difference between gender with career adapt-ability $(t=-.306, p>.05)$ and social support $(t=1.240, p>.05)$. This analysis also showed the mean score for career adapt-ability (male Mean $=4.05, \mathrm{SD}=.643$, and female Mean $=4.09, \mathrm{SD}=.570$ ). Meanwhile, the mean score for social support (male Mean $=5.20$, $S D=1.16$, and female Mean $=5.50, S D=1.19$ ). This score clearly describes both genders have high career self-efficacy. Thus, hypothesis failed to be rejected.

Table 4: Difference between gender for career adapt-ability and social support

\begin{tabular}{lllcccc}
\hline & Gender & N & Mean & SD & t & Sig. \\
\hline \multirow{2}{*}{ Career Adapt-Ability } & Male & 38 & 4.05 & .643 & -.306 & .760 \\
Social Support & Female & 45 & 4.09 & .570 & & \\
& Male & 38 & 5.20 & 1.16 & 1.240 & .219 \\
& Female & 45 & 5.50 & 1.19 & & \\
\hline
\end{tabular}

$*_{p}<.05$

\section{Discussion and Suggestions}

The findings of this study show that the career adapt-ability and social support such as family, friends and significant individuals of trainee teachers are at a high level. Good adaptation positively affects career and life due to no conflict between work stress and other 
responsibilities in life (Rudolph, et al., 2017). Adaptation affects work stress and level of desire to quit work such as individuals with high level of career adapt-ability have low level of stress and desire to quit work (Rudolph, et al., 2017).

The study also found that there was a significant relationship between adapt-ability and support from friends, but there was no significant relationship between career adapt-ability with family and significant individuals. This study shows that the career adapt-ability of trainee teachers is influenced by friends, in line with the findings of a study by Wang et al. (2017) who found that friends support showed a high score compared to support from colleagues and parents in career adapt-ability. Individuals who receive social support from parents, friends and significant individuals have better career adapt-ability (Wang, et al., 2017; Hui et al., 2018; Murviana, et al., 2019); also psychosocial functioning (Michaeli, et al., 2018).

However, the findings were contrast from the findings by Lakey and Orehek (2011); Sahin and Kirdok (2018) who found that social support from family is a high predictor of student career adapt-ability and lack of stress (Saeed et al., 2013). In addition, this study found that friends are the lowest predictors of student career adapt-ability while teachers obtain a moderate level in predicting student career adapt-ability. This is because of the support gained from the family such as career knowledge, verbal, emotional and financial support as well as role models to students (Vela et al., 2018). Similarly, the findings, show that social support from family and friends does not contribute to good stress response when it comes to career adaptability (Stoltz, et al., 2013)

This study is a new contribution in the field of education to understand the changes of the generation affecting career adapt-ability today. During school days the influence from family is strong, but when entering the university world, the influence and support from friends is stronger and more prominent. This is supported by Hirschi, et al (2011) who show that friends have a strong influence on career development including during career selection. This is because trainee teachers spend more time at university with friends and share a lot about their developments and situations faced in the classroom and while undergoing internship training (Wang et al., 2017).

In addition, this study has implications for the role of counselors in developing student career programs in terms of adapt-ability (Di Maggio, et al., 2020; Buyukoze-kavas (2016) and social support (Koto, et al., 2019). Savickas (2012) stated that counselors need to identify individuals with low levels of adapt-ability because these individuals do not have the resources to adapt and face challenges in academics and careers. Individuals with high career adapt-ability tend to have high levels of self-efficacy of career search (Tolentino, et al., 2019; Guan et al., 2013), career choices (Ashari, et al., 2019), cross-cultural adjustment (Hua et al., 2019) and teamwork skills (De Guzman \& Choi, 2013).

In fact, this study also has implications for trainee teachers so that they are aware of the importance of long-term social support for the formation of a prosperous self. This study is also seen to provide awareness to trainee teachers to prepare themselves with complete preparation in terms of emotional, mental, and physical before undergoing practicum training and facing the real world of work. The recommendations of this study are (i) counselors need 
to know and be skilled in the use of an instrument (Wahed, et al., 2019) and (ii) further research should focus on experimental studies to measure the impact on a career program implemented.

\section{Conclusion}

In conclusion, this study was conducted to find out the level and relationship between career adapt-ability and social support among trainee teachers. This study adds value to the existing study because the findings obtained from this study can help in the aspect of personal development of trainee teachers and counselors. This is because trainee teachers can find out the support from who can improve their adapt-ability level and counselors can implement counseling sessions more effectively when faced with the issue of student career adaptability.

\section{Acknowledgement}

This research is funded by UKM Grant GG-2020-009 and GG-2020-022. Funding in this paper is part of a research grant.

\section{References}

Ashari, Z. H. M., Azman, N., \& Rasul, M. S. (2019). Factors predicting career choice among Malaysian students in skills-based training institutions. International Journal for Educational and Vocational Guidance, 19(1), 19-39.

Abdul Rahim, A. (2012). Beban Tugas Guru Sekolah Menengah di Daerah Batu Pahat, Johor Darul Takzim. Unpublished Doctoral Thesis. Johor Darul Takzim: Universiti Teknologi Malaysia.

Brannon, L., \& Feist, J. (2004). Health psychology: An introduction to behaviour and health. Toronto, Canada: Thomson Wadworth.

Buyukgoze-Kavas, A. (2016), Predicting career adaptability from positive psychological traits. The Career Development Quarterly, 64: 114-125.

Buyukgoze-kavas, A. (2016). Predicting career adapt-ability from positive psychological traits. The Career Development Quarterly. Volume 64.

De Guzman, A. B., \& Choi, K. O. (2013). The relations of employability skills to career adaptability among technical school students. Journal of Vocational Behavior, 82(3), 199-207.

Di Maggio, I., Ginevra, M. C., Santilli, S., Nota, L., \& Soresi, S. (2020). The role of career adaptability, the tendency to consider systemic challenges to attain a sustainable development, and hope to improve investments in higher education. Frontier in Psychology. (11), 1926.

Fantilli, R. D., \& McDougall, D. E. (2009). A study of novice teachers: Challenges and supports in the first years. Teaching and teacher education, 25(6), 814-825.

Guan, Y. J., Deng, H., Sun, J. Q., Wang, Y. N., Cai, Z. J. Ye, L. H., Li, Y. H. (2013). Career adaptability, job search self-efficacy and outcomes: A three-wave investigation among Chinese university graduates. Journal of Vocational Behavior, 83(3), 561-570.

Hirschi, A., Herrmann, A., and Keller, A. C. (2015). Career adaptivity, adaptability, and adapting: a conceptual and empirical investigation. Journal Vocational Behavior. 87, 110. 
Hirschi, A., Niles, S. G., \& Akos, P. (2011). Engagement in adolescent career preparation: Social support, personality and the development of choice decidedness and congruence. Journal of Adolescence, 34(1), 173-182.

Hua, J., Fan, J., Walker, A., Hou, N., Zheng, L., \& Debode, J. (2019). Examinations of the role of individual adaptability in cross-cultural adjustment. Journal of Career Assessment, 27(3), 490-509.

Hui, T., Yuen, M., \& Chen, G. (2018). Career adaptability, self-esteem, and social support among Hong Kong University students. Career Development Quarterly.

Hui, T., Yuen, M., \& Chen, G. (2018). Career adaptability, self-esteem, and social support among Hong Kong University students. The Career Development Quarterly, 66(2), 94106.

Işık, E., Yeğin, F., Koyuncu, S., Eser, A., Çömlekciler, F., \& Yıldırım, K. (2018). Validation of the career adapt-abilities scale-short form across different age groups in the Turkish context. International Journal for Educational and Vocational Guidance, 18(3), 297-314.

Kementerian Pendidikan Malaysia. (2016). Pelan Induk Pembangunan Profesionalisme Keguruan. Bahagian Pendidikan Guru, KPM, Putrajaya.

Lakey, B., \& Orehek, E. (2011). Relational regulation theory: A new approach to explain the link between perceived social support and mental health. Psychological Review, 118(3), 482-495.

Mahmud, M. I., Abu Bakar, A. Y., Amat, S., Hasri, N. Z. (2021) Initial validation of Career Thought Inventory (CTI) on university students in Malaysia. Turkish Online Journal of Qualitative Inquiry (TOJQI), 12 (7), 2878 - 2886.

Mahmud, M. I., Kee, C. P., Othman, Z., Amat, S. (2020). Career self-efficacy among undergraduate student in a university. Akademika, 90(3), 167-175.

Michaeli, Y., Dickson, D. J., \& Shulman, S. (2018). Parental and nonparental career-related support among young adults: antecedents and psychosocial correlates. Journal of Career Development.

Ministry of Education (MOE). (2013). Malaysia Education Blueprint 2013-2025. https://www.moe.gov.my/menumedia/media-cetak/penerbitan/dasar/1207malaysia-education-blueprint-2013-2025/file

Bukhori, M. F., Daud, R., Rahim, N. F., Ahmad, N. A., Mustapha, M. A., Azizan, F. L., Zailani, M. A., \& Gopal, R. D. J. (2015). Kajian empirikal awal terhadap pola kecenderungan pemilihan aliran pengajian peringkat pra-universiti oleh pelajar lepasan Sijil Pelajaran Malaysia (SPM). Jurnal Personalia Pelajar. 18 (1): 29-43.

Wahed, M., Mahmud, M. I., Ghazali, S.H. (2019). Pola minat kerjaya dan penyesuaian kerjaya pelatih kor sukarelawan polis siswa/i di universiti awam. Southeast Asia Psychology Journal, 7 (4), 60 -72).

Monteiro, S. C., \& Almeida, L. S. (2015). The relation of career adaptability to work experience, extracurricular activities, and work transition in Portuguese graduate students. Journal of Vocational Behavior, 91, 106-112.

Nasir, R., Zamani, A. Z., Khairudin, R., Sulaiman W. S., Sani, M. N., \& Amin, A. S. (2016). Hubungan antara kesunyian dan sokongan sosial terhadap kemurungan dalam kalangan wanita hamil tanpa nikah. Jurnal Psikologi Malaysia. 30 (1)152-159.

Othman, N., \& Md. Omar, H. (2014). Beban tugas dan motivasi pengajaran guru di sekolah menengah Daerah Ranau. Journal for Educational Thinkers, 5, 35-57. 
Oztemel, K., \& Akyol, E. (2019). The predictive role of happiness, social support, and future time orientation in career adaptability. Journal of Career Development.

Rudolph, C. W., Lavigne, K. N., \& Zacher, H. (2017). Career adaptability: A meta-analysis of relationships with measures of adaptivity, adapting responses, and adaptation results. Journal of Vocational Behavior, 98, 17-34.

Saeed, R., Mussawar, S., Lodhi, R. N., Iqbal, A., Nayab, H. H., \& Yaseen, S. (2013). Factors affecting the performance of employees at workplace in the banking sector of Pakistan. Middle East Journal of Scientific Research, 17 (9), 1200-1208.

Sahin, I. \& Kirdok, O. (2018). Investigation of relationship between high school students' career adaptability, subjective well-being, and perceived social support. International Education Studies. Vol 11. No 8.

Savickas, M. L., \& Porfeli, E. J. (2012). Career adapt-abilities scale: construction, reliability and measurement equivalence across 13 countries. Journal of Vocational Behavior, 80(3), 661-673.

Stoltz, K. B., Wolff, L. A., Monroe, A. E., Farris, H. R., \& Mazahreh, L. G. (2013). Adlerian lifestyle, stress coping, and career adaptability: Relationships and dimensions. The Career Development Quarterly, 61(3), 194-209.

Tolentino, L. R., Sibunruang, H., \& Garcia, P. R. J. M. (2019). The role of self-monitoring and academic effort in students' career adaptability and job search self-efficacy. Journal of Career Assessment, 27(4), 726-740.

Vela, J. C., Sparrow, G. S., Whittenberg, J. F., \& Rodriguez, B. (2018). The role of character strengths and importance of family on Mexican American college students' career decision self-efficacy. Journal of Employment Counseling 55(1):16-26

Wang, L., Tao, H., Bowers, B. J., Brown, R., \& Zhang, Y. (2018). Influence of Social Support and Self-Efficacy on Resilience of Early Career Registered Nurses. Western Journal of Nursing Research, 40(5), 648-664.

Zimet, G. D., Dahlem, N. W., Zimet, S. G., \& Farley, G. K. (1988). The multidimensional scale of perceived social support. Journal of personality assessment, 52(1), 30-41. 